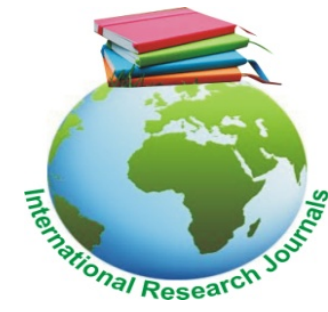

International Research Journal of Agricultural Science and Soil Science (ISSN: 2251-0044) Vol. 6(2) pp. 020-024, May, 2016

Available online http://www.interesjournals.org//RJAS

DOI: http:/dx.doi.org/10.14303/irjas.2016.019

Copyright $\odot 2016$ International Research Journals

Full Length Research Paper

\title{
Chlorite effects compared to sulfate in combination with forms of nitrogen on yields of oat and Chinese cabbage
}

\author{
Avonyo K. A. \\ University of Lomé, Superior School of Agronomy, BP 1515, Lome (Togo) \\ Corresponding Author's Email: avonyokossi@yahoo.fr
}

\begin{abstract}
To valorise sediments of iron mineral extraction zone of about 2500ha of coverage in Liberia, a concept of appropiate fertilizer was developed. A comparative study was carried out on two types of soil : a soil riched in organic matter called arable land and a soil formed exclusively with sediments called sediments or Tailings Pond. The results revealed that the choice of fertilizer types and forms played an important role in yield increase. Therefore, the best yields were obtained with the combination of the different forms of Nitrogen fertilizers and different forms of calcium and potassium fertilizers. The use of sawdust as supportive organic matter, from the different combinations, has increased or dercreased the yields of the two types of soils.
\end{abstract}

Keywords : Sediments, sawdust, manures, oat, chinese cabbage.

\section{INTRODUCTION}

The Bong Mining Company has been mining since 1960s an iron deposit in Bong County in Liberia. The importance of this mine lies on the number of employees who are working in. Europeans settled in this mining region. In fact, this mining socieity has attracted many labours from different regions of the country.

Presently, a small town with 40,000 inhabitants is founded in the region. The dwellers relyon small mining related craft activities to survive. The supply of foods, such as vegetables, comes from far distance where farming system is mostly shifting cultivation. Rice in paticular is imported from outside. For agricultural production, farmers of the region lack, not only knowledge, but also space for farming. It must benoticed in general that peoples settled in this region will lack,in the long term, food supply for their subsitence. In addition, the iron deposit is projected to finish in the short future; and the anticipated close of the company could occur due to the rentability challenge related to the evolution of the new iron industry. The return of this population to their different tribes of origin will not be possible with out difficulties. This problematic situation is well known of the managers of the mine.
Consequeently, efforts have been putin place to finance local activities development and food supply through agricultural intensification. Mountainous aspect of the region could be an obstacle to agricultural development due to erosion challenge. The same natural factors do not favour the valorization of the zone. The goal of this project is to come out with research methods for the valorization of this swampy sediment called 'Tailings Pond', which covers the surface area of approximatively 2500 ha. The point of view of Sommer (1975) is against the general opinion because of the infertility of the zone. The reasons are the soil poverty in nutrients associeted with the muddy and strucutreless status of the sediment at the one hand, and at the other hand its content in ironwhichis of $10 \%$. The adavantage of these surfaces is that they are piled up flattened; its proximity to the region, its exploitation by the native farmers who have a high qualified trainings killed associeted with a help from an agricultural project implemented in the region since a while. The condition to succeed this research work is the elaboration of a concept of an appropiate fertilizer to this type of soil which would contribute to its valorization. The aim of this 
trial is to study whether and how the anions of mineral fertilizers such as nitrate, chlorite and sulfate would influence the availability of the nutrients (sulfate in particular) in the high acid soils. It is why ammonium nitrate and calcium nitrate were chosen as nitrogen fertilizer in the program. The chloride and sulphate were applied in potassium form. The chloride and sulphate were chosen in the program because they have basic reaction in the normal conditions with the rest of the anions in soil (Villachica et al. 1974; Thung, 1975;Chien et al., 1988).

\section{MATERIALS AND METHODS}

\section{Methods of analysis of soil samples}

\section{Experimental design}

The experimental design comprised sixteen treatments with four replications of two types of soil. The soil samples were put in pots in green house according to the system of Kick-Brauchmann (1964). The treatments were arranged on the tracks that are provided each with a guage to record the water level at each stage of plant growth. The system then enables to move the experimental device out of the green house according to the climatic hazards. These trials were carried out at the Agrochemestry Institute of the University of Bonn, in Germany.

\section{Soil samples}

All the nutrients in the soil samples were disolved in a solution mixed with $1 \mathrm{~N} \mathrm{HCl}$ and $1 \mathrm{~N} \mathrm{H}_{2} \mathrm{SO}_{4}$ at the respective proportion of $1: 3$ called "Königswasser". The $\mathrm{pH}$ of the soils were determined after dilution of the samples in the solution described as follows :distilled water ; $0.01 \mathrm{M} ; \mathrm{CaCl}_{2} ; 0.05 \mathrm{M} \mathrm{K} \mathrm{K}_{2} \mathrm{SO}_{4}$ according to Jensen's method. The carbon content was determined using the method of Lichterfeld; total nitrogen by the method of Forester (1980); the available phosphate by the method of Schachtschabel(1984); and calcium and potassium were determined by the flame photometer. The results were presented in Table I.

\section{Experimental materials}

\section{a) The soil samples}

The soil samples were collected from Liberia. They were two types of soils and were as follows :

Arable land : a fertile soil of the Region.

Tailings Pond :Sediments extracted from the iron mine factory. These sediments contained $15 \%$ of iron of dark gray and powdery colour.

\section{b) Organic and mineral manures}

The nitrogen was applied in two forms at the rate of $1 \mathrm{~g} \mathrm{~N}$ per pot each. The treatments1, 3, 5, 7, 8 and 16 received ammonium nitrate $\left(\mathrm{NH}_{4} \mathrm{NO}_{3}\right)$ respectively, while the treatments 2, 4, 6, 9-15 were enriched with calcium nitrate $\left(\mathrm{Ca}\left(\mathrm{NO}_{3}\right)_{2}\right)$. The phosphate was applied in very soluble form $\left(\mathrm{KH}_{2} \mathrm{PO}_{4}\right)$ at $0.8 \mathrm{~g} \mathrm{P}$ per pot and the magnesium in form of magnesium sulfate $\left(\mathrm{MgSO}_{4}\right)$ at $0.6 \mathrm{~g}$ de $\mathrm{Mg}$ per pot. The potassium was applied in form of potassium chloride $(\mathrm{KCl})$ for the treatments 1 to 4,11 and 12, whilst the treatments 5 to 10 and 13 to 15 wereenrichedwith potassium sulfate $\left(\mathrm{K}_{2} \mathrm{SO}_{4}\right)$ at the dose of $0.99 \mathrm{~g} \mathrm{~K}$ per pot respectively. All the treatments received each $1 \mathrm{~g} \mathrm{~K}$ per pot due to the dose of potassium $(0.1 \mathrm{~g} / \mathrm{pot})$ contained in the phosphate fertilizerapplied. To address magnesium deficiency often noticed in tropical soils, the magnesium was applied in form of $\mathrm{MgSO}_{4}$ at the dose of $0.6 \mathrm{~g} \mathrm{Mg}$ per pot. The calcium was applied in form of calcium chloride $\left(\mathrm{CaCl}_{2}\right)$ to the treatments 1,3 and 4 at the dose of $1.43 \mathrm{~g} \mathrm{Ca}$ per pot; and in form of calcium sulfate $\left(\mathrm{CaSO}_{4}\right)$ to the treatments 7,9 and14 at the dose of $1.43 \mathrm{~g}$ Ca per pot and to the treatments 8,10 , 15 and 16 at the dose of $4.29 \mathrm{~g} \mathrm{Ca}$ per pot. Each treatment was enriched with micro-elements described as follows :

$\mathrm{CuSO}_{4:} 16 \mathrm{mg} \mathrm{Cu} /$ pot

$\mathrm{MnSO}_{4}: 14.6 \mathrm{mg} \mathrm{Mn} / \mathrm{pot}$

$\mathrm{H}_{3} \mathrm{BO}_{3}$ : $5.0 \mathrm{mg} \mathrm{B} /$ pot

$\mathrm{ZnSO}_{4}: 16.7 \mathrm{mg} \mathrm{Zn/pot}$

$\left(\mathrm{NH}_{4}\right)_{2} \mathrm{MoO}_{4}$ : 3.3mg Mo/pot.

Finally, the treatments 11 to 16 received $60.0 \mathrm{~g}$ per pot of sawdusteach as source of organicmatter.

\section{c) test crops}

Oat (Avenae sativa) waschosen as main crop; chinesecabbage (Brassicae ssp) and perennial Lolium were respectively selected as relay crops.

\section{Analytic study of the samples of the test crops}

To determine the yield components, the different test crop samples were dried at $105^{\circ} \mathrm{C}$ in stove for three days. To determine the mineral elements in the samples, the mean of the four replications of each treatment was finely grounded in a mill. The grains and straws were separately incinerated at $450^{\circ} \mathrm{C}$ in an oven; then the following nutrients were determined: 
022 Int. Res. J. Agric. Sci. Soil Sci.

Table I : Some chemical characteristics of the soils.

\begin{tabular}{lccc}
\hline Characteristics & Arable land & Sediments & Sawdust \\
\hline $\mathrm{C}$ Total & 1.77 & 0.14 & 4.11 \\
$\mathrm{~N}$ Total & 0.12 & 0.06 & 0.09 \\
$\mathrm{C} / \mathrm{N}$ & 14.75 & 2.34 & 41.67 \\
$\mathrm{P}_{2} \mathrm{O}_{5}(\mathrm{méq} / 100 \mathrm{~g})$ & 2.50 & 2.24 & - \\
$\mathrm{Mg} \mathrm{M} . \mathrm{NaCl}) \mathrm{mg} / 100$ & 0.72 & 0.69 & - \\
$\mathrm{K}_{2} \mathrm{O}^{*}$ & 3.32 & 2.86 & - \\
eau & 5.5 & 7.6 & - \\
$\mathrm{pH} 0.01 \mathrm{CaCl}_{2}$ & 4.2 & 6.8 & - \\
$0.05 \mathrm{M} \mathrm{K}_{2} \mathrm{SO}_{4}$ & 4.1 & 6.6 & - \\
\hline
\end{tabular}

Table 2 : Yields of oat

\begin{tabular}{lllccc}
\hline \multirow{2}{*}{ Treatments } & Forms of $\mathrm{N}$ & Forms of $\mathrm{K}$ & Grain & \multicolumn{2}{c}{ Sendements en g / pot } \\
Straw & Grain + Straw \\
\hline \multirow{2}{*}{ Arable land } & & & & & \\
1 & $\mathrm{NH}_{4} \mathrm{NO}_{3}$ & $\mathrm{KCl}$ & 101.1 & 95.2 & 195.3 \\
2 & $\mathrm{Ca}\left(\mathrm{NO}_{3}\right)_{2}$ & $\mathrm{KCl}$ & 98.4 & 79.4 & 178.0 \\
5 & $\mathrm{NH}_{4} \mathrm{NO}_{3}$ & $\mathrm{~K}_{2} \mathrm{SO}_{4}$ & 84.4 & 88.5 & 172.9 \\
6 & $\mathrm{Ca}\left(\mathrm{NO}_{3}\right)_{2}$ & $\mathrm{~K}_{2} \mathrm{SO}_{4}$ & 96.3 & 92.8 & 189.1 \\
Sediments & & & & & \\
1 & $\mathrm{NH}_{4} \mathrm{NO}_{3}$ & $\mathrm{KCl}$ & 75.9 & 81.6 & 157.5 \\
2 & $\mathrm{Ca}\left(\mathrm{NO}_{3}\right)_{2}$ & $\mathrm{KCl}$ & 91.0 & 79.6 & 170.6 \\
5 & $\mathrm{NH}_{4} \mathrm{NO}_{3}$ & $\mathrm{~K}_{2} \mathrm{SO}_{4}$ & 50.3 & 61.7 & 112.0 \\
6 & $\mathrm{Ca}\left(\mathrm{NO}_{3}\right)_{2}$ & $\mathrm{~K}_{2} \mathrm{SO}_{4}$ & 85.4 & 92.7 & 178.1 \\
\hline CV5\% & & & 7.0 & 9.2 & 13.5 \\
\hline
\end{tabular}

Table 3.Yield of dry matter (DM) of chinesecabbage

\begin{tabular}{llll}
\hline Treatments & Forms of $\mathbf{N}$ & Forms of $\mathbf{K}$ & DM. g/pot \\
\hline Arable land & & $\mathrm{KCl}$ & \\
1 & $\mathrm{NH}_{4} \mathrm{NO}_{3}$ & $\mathrm{KCl}$ & 12.3 \\
2 & $\mathrm{Ca}\left(\mathrm{NO}_{3}\right)_{2}$ & $\mathrm{~K}_{2} \mathrm{SO}_{4}$ & 16.9 \\
5 & $\mathrm{NH}_{4} \mathrm{NO}_{3}$ & $\mathrm{~K}_{2} \mathrm{SO}_{4}$ & 13.7 \\
6 & $\mathrm{Ca}\left(\mathrm{NO}_{3}\right)_{2}$ & & 18.2 \\
Sediments & & $\mathrm{KCl}$ & 24.6 \\
1 & $\mathrm{NH}_{4} \mathrm{NO}_{3}$ & $\mathrm{KCl}$ & 21.0 \\
2 & $\left.\mathrm{Ca}_{2} \mathrm{NO}_{3}\right)_{2}$ & $\mathrm{~K}_{2} \mathrm{SO}_{4}$ & 23.7 \\
5 & $\mathrm{NH}_{4} \mathrm{NO}_{3}$ & $\mathrm{~K}_{2} \mathrm{SO}_{4}$ & 28.0 \\
6 & $\mathrm{Ca}\left(\mathrm{NO}_{3}\right)_{2}$ & & 2.5 \\
\hline PPDS 5\% & & & \\
\hline
\end{tabular}

Phosphate through ammonium-vanadate method (Gericke et Kurmies 1952), Potassium and calcium by Gettkandt (1965) method,

Magnesium and the micro-elements with the atomic absorption spectrometry

Nitrogen by the Kjeldahl distillation mixed with selenium of Winninger cited in Naumann et al. (1976).

The evaluation of the experiment results was done through ANOVA with three factorials of Schuster, (1978).

\section{RESULT AND DISCUSSION}

Table 2 showed that the application of potassic fertilizer in form of chlorite produced the best yields for all the treatments. 1 and 5 compared to the treatments 2 and 6 which were enriched with calcium nitrate and potassium sulfate. In addition, it was noticed adecrease of yields for the treatment 5 for the twosoil types. Independently to the form of the nitrogen applied, treatments enriched with 
Table 4: Nitrogen content and quantity exported from oat

\begin{tabular}{lccccccccccccc}
\hline & \multicolumn{4}{c}{ Content inN (\%) Quantity of Nexported (mg/pot) } & \multicolumn{4}{c}{ Average (\%) N } \\
\multicolumn{4}{c}{ Grain } & \multicolumn{2}{c}{ Staw } & \multicolumn{1}{c}{ Grain } & Straw & \multicolumn{2}{c}{ Total } & & \\
\multicolumn{1}{l}{ Treatments. a.I } & sed & a.I & sed & a.I & sed & a.I & sed & a.I & sed & a.I & sed \\
\hline 1 & 1.18 & 1.38 & 0.44 & 0.23 & 1181 & 1052 & 421 & 188 & 1602 & 1240 & 80 & 62 \\
2 & 2.02 & 1.32 & 0.48 & 0.14 & 2094 & 1203 & 388 & 123 & 2482 & 1326 & 124 & 66 \\
5 & 2.03 & 1.31 & 0.53 & 0.19 & 1717 & 661 & 477 & 118 & 2194 & 779 & 109 & 38 \\
6 & 1.90 & 1.25 & 0.50 & 0.19 & 1834 & 1074 & 463 & 184 & 2297 & 1258 & 114 & 63 \\
\hline
\end{tabular}

Table 5. Phosphorus content and quantity exported from aot.

\begin{tabular}{|c|c|c|c|c|c|c|c|c|c|c|}
\hline \multirow[b]{3}{*}{ Treatements: } & \multicolumn{4}{|c|}{ Content in P (\%) } & \multicolumn{6}{|c|}{ Quantity of P exported (g/ pot) } \\
\hline & \multicolumn{2}{|c|}{ Grain } & \multicolumn{2}{|c|}{ Straw } & \multicolumn{2}{|c|}{ Grain } & \multicolumn{2}{|c|}{ Straw } & \multicolumn{2}{|c|}{ Total } \\
\hline & a.l & sed & a.l & sed & a.I & sed & a.I & sed & & sed \\
\hline 1 & 0.83 & 0.92 & 0.10 & 0.13 & 830 & 70 & 102 & 106 & 932 & 807 \\
\hline 2 & 0.82 & 0.83 & 0.09 & 0.07 & 849 & 757 & 78 & 65 & 927 & 822 \\
\hline 5 & 0.96 & 0.93 & 0.14 & 0.11 & 810 & 446 & 130 & 70 & 940 & 538 \\
\hline 6 & 0.88 & 0.93 & 0.11 & 0.10 & 846 & 791 & 108 & 92 & 954 & 883 \\
\hline
\end{tabular}

a.I : arable land sed : sediments

Table 6. Content and quantity of $\mathrm{K}$ exported from oat.

\begin{tabular}{|c|c|c|c|c|c|c|c|c|c|c|}
\hline \multirow[b]{3}{*}{ Treatments } & \multicolumn{4}{|c|}{ Content in K (\%) } & \multicolumn{5}{|c|}{ Quantity of K exported (g/pot) } & \multirow[b]{3}{*}{ sed } \\
\hline & \multicolumn{2}{|c|}{ Grain } & \multicolumn{2}{|c|}{ Straw } & \multicolumn{2}{|c|}{ Grain } & \multicolumn{2}{|c|}{ Straw } & \multirow{2}{*}{$\begin{array}{r}\text { Total } \\
\text { a.l. }\end{array}$} & \\
\hline & a.l & sed & a.l & sed & a.l & sed & a.I & sed & & \\
\hline 1 & 1.03 & 1.23 & 2.52 & 3.31 & 1039 & 935 & 2397 & 2700 & 3436 & 3635 \\
\hline 2 & 1.09 & 0.94 & 2.91 & 3.31 & 1135 & 856 & 2320 & 2768 & 3455 & 3624 \\
\hline 5 & 1.10 & 1.14 & 2.52 & 2.67 & 933 & 575 & 2230 & 1646 & 3163 & 2221 \\
\hline 6 & 1.12 & 1.17 & 2.52 & 3.31 & 1083 & 1000 & 2337 & 3067 & 3420 & 4070 \\
\hline
\end{tabular}

a.l : arable land

sed : sediments

Table 7. Content and .quantity of Mg exported from oat.

\begin{tabular}{|c|c|c|c|c|c|c|c|c|c|c|}
\hline \multirow{3}{*}{$\begin{array}{c}\text { Grain } \\
\text { Treatments. }\end{array}$} & \multicolumn{4}{|c|}{ Content in $\mathrm{Mg}(\%)$} & \multicolumn{5}{|c|}{ Quantity of Mg exported (mg/ pot) } & \multirow[b]{3}{*}{ sed } \\
\hline & \multicolumn{2}{|c|}{ Straw } & \multicolumn{2}{|c|}{ Grain } & \multicolumn{2}{|c|}{ Straw } & \multicolumn{3}{|c|}{ Total } & \\
\hline & a.l & sed & a.l & sed & a.l & sed & a.I & sed & a.I & \\
\hline 1 & 0.97 & 0.91 & 0.12 & 0.05 & 978 & 697 & 115 & 46 & 1094 & 743 \\
\hline 2 & 0.83 & 0.98 & 0.16 & 0.04 & 867 & 894 & 129 & 35 & 996 & 929 \\
\hline 5 & 0.69 & 0.76 & 0.15 & 0.03 & 589 & 385 & 132 & 19 & 722 & 404 \\
\hline 6 & 0.26 & 0.88 & 0.14 & 0.04 & 257 & 755 & 129 & 45 & 87 & 800 \\
\hline
\end{tabular}

a.l : arable land;

sed : sediments

chlorite had a higher yields compared to those enriched with sulfate. Arable land favoured yields than sediments.
There were interactions between soil types and the forms of nitrogen and potassium. Besides, clacium content was 
024 Int. Res. J. Agric. Sci. Soil Sci.

Table 8. Content andquantity of Ca exportedfrom oat.

\begin{tabular}{lcccccccccrr}
\hline & \multicolumn{3}{c}{ Content in Ca (\%) } & \multicolumn{4}{c}{ Quantity of Caexported(mg/pot) } \\
& \multicolumn{3}{c}{ Grain } & \multicolumn{2}{c}{ Straw } & \multicolumn{2}{c}{ Grain } & Straw & \multicolumn{2}{c}{ Total } \\
Treatments. & a.l & sed & a.l. & sed & a.l & sed & a.l & sed & a.l & sed \\
\hline 1 & 0.60 & 0.55 & 2.89 & 1.45 & 60 & 42 & 274 & 118 & 335 & 160 \\
2 & 0.55 & 0.45 & 4.18 & 1.75 & 57 & 41 & 333 & 146 & 390 & 187 \\
5 & 0.50 & 0.45 & 2.79 & 1.00 & 42 & 22 & 247 & 61 & 289 & 84 \\
6 & 0.75 & 0.40 & 3.78 & 1.20 & 72 & 34 & 351 & 116 & 424 & 150 \\
\hline
\end{tabular}

a.l : arable land ;

sed : sediments

Table 9: Content in micro-éléments $\mathrm{Zn}$ and Fe for oat

\begin{tabular}{|c|c|c|c|c|c|c|c|c|c|c|c|c|c|}
\hline \multirow[b]{3}{*}{ Treatments. } & \multicolumn{4}{|c|}{ Mn (mg/kg) } & \multicolumn{4}{|c|}{$\mathrm{Zn}(\mathrm{mg} / \mathrm{kg})$} & \multicolumn{4}{|c|}{$\mathrm{Fe}(\mathrm{mg} / \mathrm{kg})$} & \\
\hline & \multicolumn{2}{|c|}{ Grain } & \multicolumn{2}{|c|}{ Straw } & \multicolumn{2}{|c|}{ Grain } & \multicolumn{2}{|c|}{ Straw } & \multicolumn{2}{|c|}{ Grain } & Straw & & \\
\hline & a.l. & sed & a.l & sed & a.l & sed & a. & sec & & a.l sed & a.l & & \\
\hline 1 & 72 & 59 & 71 & 82 & 54 & 27 & 47 & 15 & 189 & 193 & 133 & 149 & \\
\hline 2 & 52 & 42 & 52 & 54 & 52 & 9 & 35 & 14 & 136 & 126 & 93 & 90 & \\
\hline 5 & 56 & 60 & 56 & 77 & 55 & 22 & 23 & 14 & 146 & 129 & 246 & 100 & \\
\hline 6 & 81 & 54 & 81 & 45 & 47 & 19 & 27 & 12 & 216 & 123 & 133 & 80 & \\
\hline
\end{tabular}

low at the flowering stage of oat.

\section{REFRENCE}

Bonn, Dachverband wiss. Gesellschaften der Agrar-, Forst-, Ernahr-, Veter-, und Umweltschutz e-V., Munchen.

Chen Q, Li X, Horlacher D, Liebig HP (2004). Effects of different nitrogen rates on open field vegetable growth and utilization in the North China Plain. Soil Sci. and Plant Analysis. 35: 1725-1740.

Chien SH, Friesen DK, Hamilton DW (1988). Effect of application method on availability of element sulfur in copping sequences. Soil Soc. Of Amer. J. 52 (1), 165-169.

Foerster H (1980). Einflub von unterschiedlich starken Magnesiummangel bei Gerste auf den Kornertrag und seine komponenten, Z. Pflanzenernahr. Bodenkdde. 143: 627-637.

Gericke, Kurmies (1952). Die kolorinetrische Phosphorsaune bestimmung mit Ammonium-Vanadat und ihre Auswertung in der Pflanzen analyse. Z. Pflanzern. Und Bodenkde 59: 235-247.

Gettkandt G (1956). ein Beitrag zur Flammen-photonetrische Calciumbestimmung in Pflanzenasche. Z. Pflanzenern. u. Bodenkde 74: 135-139.

Giroux M (1982). Etude comparative du chlorure et de sulfate de potassium sur le rendement, la nutrition et la qualité des tubercules. Agric. $82: 9-12$.

Guo Z, Wang H (2013). Long-term effects of returning Wheat strow to cropland on soil, compaction and nutrient availability under conventional tillage. Plant Soil Environ. 59: 280-286.

Harter R (2007). Les sols acides des tropiques. Echo note technique.

Kavvadias V, Paschalidis C, Aktrivos G, Petropoulos D (2012). Nitrogen and potassium fertilization response of potato (Solanu tuberosum cV Spunta). Soil Sci. and Plant Analysis 43(1-2): 176 - 189

Kick, HE, Grosse B, (1964). Uber die Konstruktion eines Vegetationsgefasses aus Kunststoff. Z. Pflanzern. Bodenkde. 51: 367-368.

Li S O, Liu Y, Chien X (2013). Effects of increased Ammonia on roat shoot ratio, grain yield and nitrogen use efficiency of two wheat varieties with various $\mathrm{N}$ supply. Plant Soil Environ. 59: 171-176.
Maltas A, Corbeels M, Escoped E, Wery J, Macend da Silva FA (2009). Cover crop and nitrogen effects on maize productivity in no-tillage systems of the Brazilian Cerrados. Agronomy J. 101 (3) 556-559.

Nadou BK, Pure H, Singh DV (2001). Nitrogen and sulfur relations in effecting yield and quality of cereals and oilseed crops. Scientific World J. Dec. 11, 2: 30-40.

Naumann RK, Basler (1976). Die chemische Untersuchung von Futtermitteln. Methodenbuch Bd. III, 3, Aulf.: Melsungen, Berlin, Basel, Wien

Omar L, Osumanu A, Haruna F, Mohamed - MN (2016). Effecf of organic amendment derived from co - composting of chincken slurry and rice strow on reducing nitrogen loss from urea. Soil Sci. and Plant Analysis 47(5): 639 - 656

Schachtschabel P (1980). Lehrbuch der Bodenkunde 9. Auflage: Sttugart. $405 \mathrm{p}$.

Schuster, W. H. und von Lochow, J. 1978: Anlage und Auswertung von Feldversuchen, DLG - Verlag Frankfurt. $239 \mathrm{p}$.

Smith ER, Gordon C, Bourque A, Campbell S, Genermond P, Rochette M. Mkha-bela. Canadian J. of Sci. 89 (3): 357-367.

Sommer, K. und N'Doreyaho, V. 1975: Die Problemarik der Versorgung von Pflanzen nit Nahrstoff auf biberianischer Boden. Tagung uber die Pflazen in den tropen und Subtropen.

Thung, D. T. 1975: Vergleichende Untersuchungen uber die Wirkung von Phosphate mit verschiedener Loslichkeit auf Pflanzen und Boden unter semi-ariden okologischen Bedingungen, Diss. Giessen. $120 \mathrm{p}$.

Villachica H, Bornemisza E, Area M (1974). The effect of lime and macronutrient content of Pangola grass grown on a soil from Pucallpa, Peru. Agronochimica Pisa, 18: 344-353.

Wang F, Tong YA, Zhang JS, Gao PC, Coffie JN (2013). Effects of various organic materials on soil aggregate stability and soil microbiological properties on the loess Plateau in China Plant Soil Environ. 59: 162-168.

Wortmann CS, Dobermann AR, Ferguson RB, Horgert GW, Shapiro CA, Tarkalson DD, Walters I (2009) High - yielding corn response to applied. Phosphorus, potassium und sulfur in Nebraska. Agronomy J. 101 (3): 546-555. 